[pre-proofing version]

\author{
'God forbid it should come to that': the feud between \\ Colonel Molesworth and Major-General O'Brien in Portugal, 1663 $^{1}$
}

The court martial of Guy Molesworth began on 19 February 1663 in the Portuguese town of Moura. Three days later, having taken evidence from numerous officers and men of the 'English' Brigade (which was in fact Anglo-Irish), the presiding panel found the former royalist colonel guilty of speaking reproachful words against Charles II and disobeying his superiors. Molesworth was sentenced to death. ${ }^{2}$ The condemned man had made several enemies during his short time in Portugal - not least among them Major-General Christopher O'Brien, commanding the Brigade in the absence of his brother, the Earl of Inchiquin. After a lifetime of soldiering in Europe and the British Isles, followed by equally hazardous escapades in the British Atlantic, Molesworth seemed destined for an ignominious end. However, well before the court martial had been convened the colonel had alerted his personal network of friends and relatives in Whitehall and Lisbon. Influential allies were thus were already fighting to save him - at a mounting cost not only to their own political careers but also to international relations between England and Portugal.

With some notable exceptions, particularly as regards relations between England and the Netherlands, ${ }^{3}$ the study of Charles II's foreign policy has tended to be overshadowed in recent decades by an impressive procession of books and articles which have significantly revised our understanding of domestic issues within the British kingdoms. ${ }^{4}$ Much, therefore, has changed since Ronald Hutton observed that neglect of the 1660s had caused the history of the English Revolution to read 'like a marvellous story with the last chapter missing'; yet there is still much to explore. ${ }^{5}$ Steven Pincus's work on the formulation of English foreign policy, and studies by Atlantic scholars such as Carla Pestana have highlighted the benefits of considering early modern English (or increasingly British) domestic issues in a wider international setting. ${ }^{6}$ There have been a number of works on Anglo-Portuguese relations during the Restoration period, but only two published studies of the Anglo-Irish Brigade, in 1960 and 1975 respectively. ${ }^{7}$ But as the events surrounding Molesworth's court martial will demonstrate, far from being out of sight and out of mind the Anglo-Irish Brigade was an acutely sensitive issue, and had a wider significance in English politics than has hitherto been appreciated. In order to answer the questions arising from the events in Portugal, however, both the events and their central character must be viewed in context. The changing political environment and the personal circumstances which moulded Molesworth's career led him to a death sentence in Moura, but ultimately provided him with a way out.

$$
* * *
$$

In February 1635 the teenage Guy Molesworth and William Garfoote of the Inner Temple in London were convicted of harassing fellow students and attempting to provoke a duel. The eldest son of wealthy Northamptonshire gentry, Molesworth was able to deposit $£ 500$ as surety for future good behaviour. But by June he was again observed taunting a victim in the street and boasting that he cared nothing for his bond. He was charged with contempt of court, upon which his father sent him away to Europe to learn the art of soldiering in the army of Bernard of Saxe-Weimar. ${ }^{8}$ 
Molesworth proved a capable officer. In 1639, by now a company commander, he obtained permission to return home to England to join forces being raised by Charles I to repress Scotland. ${ }^{9}$ He was in England by January 1640, when he visited his brotherin-law Gervase Holles in Lincolnshire, and served as captain-lieutenant in the Earl of Northumberland's regiment during the second Bishops' War. ${ }^{10}$ In 1641 he was allotted a foot company in forces bound for Ireland. He arrived there in March 1642 under the command of Lieutenant-Colonel George Monck, and was soon promoted to major. ${ }^{11}$

In 1643, when the King began to recall regiments to serve in the royalist army in England, Monck was arrested on suspicion of harbouring parliamentarian sympathies. Molesworth, by contrast, was made lieutenant-colonel of Prince Maurice's regiment of horse. ${ }^{12}$ Molesworth had an influential contact in the shape of his kinsman Holles, now a royalist MP and colonel of his own regiment, but the origins of his association with Maurice and his brother Prince Rupert are less clear. The closeness of the relationship was exemplified in January 1645 when he wrote to Rupert to complain about the garrison authorities in Bridgwater. ${ }^{13}$ Molesworth's readiness to undermine the chain of command had already sparked a quarrel with his local superior Lord Hopton.

Unabashed, he wrote to the regional commander George Goring to request reassignment. When Goring refused Molesworth deserted his post and rode to Rupert in Oxford. This was a calculated move: Maurice was already trying to extract his regiment from Bridgwater while Goring himself was unpopular with Rupert, having recently persuaded the King to grant him exemption from the Prince's orders. Rupert was predictably unsympathetic to Goring's demands that Molesworth be court-martialled. ${ }^{14}$

Nevertheless, Molesworth removed to Bristol to seek the additional protection of the Prince of Wales's Council of War, whose Secretary, Sir Richard Fanshawe, was an intimate friend of Holles. ${ }^{15}$

When Maurice's regiment also decamped to Bristol Molesworth resumed command. During the Naseby campaign of June 1645 he was wounded and captured: a parliamentarian report some months later mentions a skirmish with 'men of Lt. Col Mole, who commands Maurice's regt and made an escape out of the Tower'. ${ }^{16}$ This incarceration had briefly brought him back into contact with George Monck, who, having convinced the royalist authorities of his loyalty, had rejoined the army only to be captured in January 1644. Transferred to the Tower in June, Monck was imprisoned there for the remainder of the first Civil War.

Molesworth's whereabouts between November 1645 and 1647 are uncertain. ${ }^{17}$ The period between September 1645 and July 1646 saw the dismissal of Rupert, Maurice and many of their associates. Even if he survived this purge, Molesworth's absence from the Calendars of Compounding indicates that his estates were now insufficient to interest the Parliamentary Commissioners. Like many royalists, he opted to emigrate.

Together with his wife and daughters, Molesworth arrived on Barbados early in 1647. Although ostensibly administered by a governor, Barbados was ruled by the leading planters sitting on the island's Assembly. The fact that Molesworth was able to become Treasurer of this body is indicative of his ability to construct effective personal networks. However, the leading royalists on Barbados, Humphrey and Edward Walrond (who had arrived from England in October 1646) were already his enemies. Humphrey Walrond had been a leading light in the Bridgwater garrison during the first Civil War the administration for which Molesworth had caused such trouble only two years earlier. His appointment was therefore unacceptable to the Walronds. Finding insufficient 
support among fellow royalists, the brothers turned to the island's leading parliamentarian, James Drax, arguing that Molesworth posed a serious threat to the common peace. He was accused of having incited a servant uprising in 1649, and having declared that 'it would never be well in this island, until the Roundheads' estates were given to the poor Cavaliers' ${ }^{18}$ Molesworth was arrested, his property seized and, he would later claim, his associates tortured. Unable to obtain sufficient evidence to justify his execution the Walronds summarily expelled the whole family from the island. Following the plundering of their unprotected ship by pirates Molesworth calculated that his total losses amounted to $£ 20,000 .^{19}$

The family sailed to Virginia. Here Molesworth built up a new plantation, and was elected to the colony's Assembly. When the monarchy was restored in 1660 he was among those selected to carry Virginia's loyal address to Charles II. ${ }^{20}$ Instead of returning to America, however, he made the fateful decision to remain in London and seek revenge. In June 1661 in a petition to the House of Lords he attributed the loss of his Barbadian estate to the 'malice and false suggestion of Sir James Drax and others', and demanded restitution. ${ }^{21}$ Unfortunately, Humphrey Walrond was now beyond his reach, having recently been appointed president of the Barbadian Assembly. ${ }^{22}$ The Walrond brothers had seized Barbados for Charles II, and their exile following the surrender of the island in 1652 had made them royalist martyrs. Similarly, despite his past associations Drax had been reconciled to the restored monarchy and knighted; his rehabilitation made smoother by the fact that his closest friend, Sir Thomas Modyford, was a kinsman of George Monck (who had now been created Duke of Albemarle in recognition of his pivotal role in the Restoration). Molesworth's petition came to nothing. ${ }^{23}$

Lobbying was expensive and Molesworth now found himself in debt. Since being appointed a Master of Requests at court alongside his friend Sir Richard Fanshawe, Gervase Holles had used his position to promote the interests of several relatives. Despite his brother-in-law's best efforts, however, Guy Molesworth was granted neither money nor position. ${ }^{24}$ With debtors' prison looming he grudgingly accepted a commission as captain of a troop of horse in forces being assembled for the aid of Portugal. It was to prove an unhappy appointment; so much so that a gloomy Molesworth was later heard to utter that he wished that Charles II 'had sent him to Tyburne when hee was sent for Portugal'. ${ }^{25}$

$* * *$

England's intervention in the Portuguese war of independence was driven by several factors. Gerald Belcher has demonstrated that Charles II was driven by the need for funds to bolster his domestic situation rather than any desire to participate in foreign affairs. According to Belcher, the Portuguese offer of a marriage alliance was 'for financial and commercial considerations, too attractive to refuse despite the possible implications for Anglo-Spanish relations' ${ }^{26}$ Catherine of Braganza's dowry included Tangier, Bombay and trading rights, together with commodities and specie estimated to have been worth half a million pounds. ${ }^{27}$ But the rivalry between France and Spain was also a significant consideration. The cold war which had existed between the two powers since the Treaty of the Pyrenees in 1659 had as one of its theatres the ongoing Portuguese struggle for independence from Spain. The French had encouraged Portuguese efforts to hire English veterans, and had even offered to finance Charles II's military commitments arising from his marriage. ${ }^{28}$ Charles' ministers for their part saw 
an opportunity to be rid of large numbers of Cromwellian veterans, together with the small pre-Restoration royalist army marooned in Flanders. In addition, many needy Cavaliers could now be given employment, with commissions that conveniently disqualified them from receiving assistance from the fund then being set up for the relief of indigent loyal officers. ${ }^{29}$

The infantry that disembarked at Lisbon in June 1662 came almost exclusively from the old Army of the Commonwealth. The cavalry were a mixture of exCromwellians, Irish troopers from Flanders and English adventurers. ${ }^{30}$ Molesworth was disappointed only to secure a captaincy at a time when several senior positions were being given to ex-parliamentarians, but in the intense competition for places he was one among many.

From the outset, several factors conspired to reignite Molesworth's proclivity for causing trouble: the pay and supplies Alfonso VI of Portugal had agreed to provide were not forthcoming and the civilian population, which had already clashed with French volunteers, was ready to murder any soldier rash enough to stray far from camp. The unpaid Brigade needed to forage and, as the soldiers were quick to avenge any injury, relations with the local community rapidly deteriorated. By November the Brigade was suffering from hunger and 'barbarous treatment'. ${ }^{31}$ Molesworth, typically, had already bypassed his commanders to complain directly to the English ambassador, who was none other than his old acquaintance Sir Richard Fanshawe. Their correspondence provides evidence of a longstanding friendship: replying on 10 October 1662, the ambassador divulged sensitive information about negotiations between Molesworth's superiors and the Portuguese, concluding with the sentiment that 'the injunctions of our Brother Gervas Holles (who presents by me his most affectionate service to you) will oblige me to remaine allwayes $\&$ and in all places your faythfull Servant. ${ }^{32}$ On 17 November Fanshawe again short-circuited the chain of command, sending Molesworth a detailed report of his efforts to secure the Brigade regular pay and a fairer price for its supplies. 'I beseech you', the ambassador wrote, 'to impart the Contents hereof, as likewise of what I have formerly written you, unto as many there as you shall judge requisite. ${ }^{33}$

But Molesworth had deeper grievances: he bitterly resented being required to serve alongside Cromwellian veterans, whom he considered rebels and traitors, and deprecated the fact that command of the Brigade had been vested in the Earl of Inchiquin and his brother, Major-General Christopher O'Brien. Whilst there is no evidence that Molesworth objected to the fact that his commanders were Catholics (he was after all a member of Fanshawe's mixed circle) he certainly objected to the fact that they were Irish turncoats. Murrough O'Brien, Earl of Inchiquin, although raised as a Presbyterian, had served his military apprenticeship in the Spanish army. He had campaigned ruthlessly against the Confederacy during the Irish uprising, but during the subsequent fighting had regularly switched sides. Although he had gone into exile with Charles II, the Earl's conversion to Catholicism while serving in the French army in 1657 had alienated many at Charles' court. In 1659, having lost his position as governor of Catalonia (which France had been obliged to cede to Spain) Inchiquin had been in transit to Portugal when he had been captured by corsairs. Charles II had secured the Earl's release in 1661 in order to give him command of the Anglo-Irish Brigade. The Catholic Inchiquin was a logical choice given that Alfonso's regime was heavily reliant upon the support of church leaders and Portuguese public opinion. It was, however, an appointment which quickly caused dissention within the Brigade. 
On 30 January 1663 Fanshawe received the alarming news that Molesworth and two other officers had been arrested. The three had been held incommunicado and without charge since 30 December on the orders of Major-General O'Brien. The prisoners further claimed that during a move between Moura and Estremos a Captain South had led an attempt to murder them. ${ }^{34}$ Although he had no jurisdiction in military matters, Fanshawe moved quickly to intervene. O'Brien had commanded the Brigade since November (Inchiquin having been recalled to London for consultations), and the ambassador now wrote to him to request that Molesworth be allowed to return to England to answer any charges. If he sought thereby to conceal the Brigade's disunity from the Portuguese Fanshawe's request was a logical one; but he was primarily concerned with the fate of Guy Molesworth. Offering to act as surety for his friend, Fanshawe declared that he would have done the same for the other officers 'if I knew them as I doe Colonell Molesworth, and withal had received such light of what there is to be objected against them, as to know them to bee Baylable' ${ }^{35}$ Having failed to gain O'Brien's consent for the court martial to take place in England, the ambassador requested that the trial be moved to Lisbon - hardly a move designed to keep the incident secret from the Portuguese. ${ }^{36} \mathrm{O}$ 'Brien refused, and the court martial convened at the Brigade's headquarters in Moura on 19 February 1663.

The president of the court, Colonel James Apsley, was a former royalist who, unlike Molesworth, had served contentedly under Goring during the first Civil War. ${ }^{37}$ Molesworth faced ten charges, ranging from insubordination to sedition and mutiny. Apsley pointed out in his subsequent report to London that the defendant had only nominated one witness (bizarrely, this was his alleged would-be assassin Thomas South), who had refused to corroborate any counter-accusations against Major-General O’Brien. ${ }^{38}$

The prosecution began with the accusation that Molesworth had impugned Charles II. Several witnesses testified that they had heard him declare that "this party were to bee made slaves of or to bee destroy[ed], and 'that if the kinge had any honest Cavaleires hee should send them to bee destroyed in a company of Rebels'. ${ }^{39}$ Such sentiments were all the more damaging for being close to the truth. The pressure on the Brigade's officers to maintain a facade of national harmony was even more evident in the fourth article on the charge sheet. A sergeant and three soldiers testified that Molesworth had 'daily disheartened the foote soldiery by tellinge them they were Cromwells whelps and Rebels and that they were sent here for murdering the late King and were as banished men. ${ }^{40}$ It can readily be appreciated that such diatribes would have further undermined the morale of troops already suffering from the consequences of official neglect. ${ }^{41}$ The sixth article alleged that Molesworth had mistreated his own men. Several officers of Molesworth's troop appeared as witnesses to confirm that he had 'defrauded many of the troops of their Pay, Corne and Grain and tooke away of their horses, and haried of the men wth out a Court martial'. ${ }^{42}$ Article Seven contained an implicit criticism of Fanshawe, as the prosecution claimed that the efforts to have the case heard by the Portuguese authorities in Lisbon had been nothing less than an attempt 'to robbe the English of that Liberty wch his Gracious Maty gave unto them to be tried by no other but by their own Lawes', ${ }^{43}$

Particularly serious were charges that Molesworth had attempted to instigate a mutiny. The trigger for this had been the withholding of four days' pay, which several 
witnesses testified Molesworth had represented to his men as 'one of the Earle of Inchiquins cheetes'. The judges were undecided on whether these comments inter alia constituted incitement to mutiny, but Molesworth had been rash enough to distribute leaflets among the common soldiers justifying his actions. A witness - the former Commonwealth officer Colonel Henry Pearson - produced one of the offending leaflets in court. ${ }^{44}$

The prosecution repeatedly emphasised the fact that the main target of Molesworth's vitriol had been Major-General O'Brien. Article Two alleged that Molesworth had declared that 'hee did not know hee [O'Brien] was true to the Kinge in any thinge but Rebellion'. ${ }^{45}$ Article Seven contended that he had repeatedly disobeyed O'Brien's orders. Article Ten alleged that the defendant had publicly declared 'that if Jesus Christ were come from Heavene and were an Irish man hee would not obey him' ${ }^{46}$ The main charge, also contained in Article Ten, alleged that Molesworth had 'abused the whole English Party in insinuatinge to many officers and souldiers in this army and in the army of the Portuguez that Major General O Brian intended wth this party to runne away to the Enemy'. ${ }^{47}$

O'Brien had already delivered himself into Colonel Apsley's custody, declaring that the 'truth thereof might bee examined before the Court'. ${ }^{48}$ This somewhat theatrical flourish appears to have drawn outside attention to the case and provided ammunition for Fanshawe, who had again begun to urge that the affair should be investigated at a higher level. In Moura, meanwhile, the court found Molesworth guilty on several counts. Twenty officers, including at least one prosecution witness (Henry Pearson), signed a document, in which they declared that,

...the penalty of the sayd articles beinge by his Matie ordayned to bee death, from which wee have noe Liberty to recede, wee doe hereby order that Collonel Guy Molesworth bee shott to death or otherwise punished and disposed of accordinge to the will of Major-Generall O'Bryan, for whose Mercy wee are supplicants. ${ }^{49}$

It is clear that the court martial was conducted according to articles of war similar to those issued to English forces in Tangier and Dunkirk; however, no copy is listed in the State Papers, neither is there an obvious match listed in John Childs' seminal work on the army of Charles II. Apart from the 'Laws and Ordinances of War' for 'his Majesty's Forces in the Kingdoms of Suz, Fez and Morocco' (1661) noted by Childs, there is a reference to a printed set of military regulations dated 4 October 1662 in an order issued by the Lord Lieutenant of Ireland in $1667 .{ }^{50}$ Most striking is the fact that the court assumed the authority to try Molesworth for seditious talk. Where treason or sedition is alluded to in pre-Restoration Articles of War, it is generally in the specific military context of betraying intelligence or giving material succour to the enemy. ${ }^{51}$ Nearcontemporaneous incidents in North Africa stand in marked contrast to the disciplinary proceedings instituted against Lieutenant-Colonel Molesworth. Despite the fact that Charles II's forces in Tangier were made up of an equally tinder-dry mixture of exparliamentarians, royalists and Irish Catholics, formal courts martial within that garrison were infrequent and appear to have involved only the normal run of military crimes. The numerous disputes between Tangier's officers all appear to have been resolved by remarkably lenient disciplinary action, even in those cases where the quarrel had ended in violence or death. ${ }^{52}$ No courts martial arose from blazing rows in 1664 between 
Tobias Bridges (an ex-New Model Army major), Henry Norwood (a Cavalier-Anglican) and the deputy governor Colonel John Fitzgerald, despite the fact that the altercations between the Irish Catholic Fitzgerald and his two subordinates are variously described as coming close to blows and being 'very high on both sides' ${ }^{53}$ Given that the Tangier garrison was hugely outnumbered, and under almost constant attack from Moorish forces, it may be that differences of opinion were invariably put aside when faced with more immediate matters of mutual concern in the daily struggle for survival. The condition of the Anglo-Irish Brigade in Portugal was scarcely less desperate, and, as will be shown, there was considerable unity between the bulk of the officers despite their very different religious and ideological backgrounds. But whilst no records of any court martial exist for the other two officers held at Estremos, Nicholas Pendennis and John Crossman, it is evident that Christopher O'Brien, supported by his senior commanders, intended to make an example of Guy Molesworth. In airing his prejudices so vociferously to fellow officers, in attempting to influence the common soldiers and particularly in communicating his suspicions to their Portuguese hosts, Molesworth had gone considerably further in his personal vendetta against his superiors than had any other argumentative officer in Tangier or Portugal. Nevertheless, as Barbara Donagan has written, even during the trials of parliamentarian officers in Oxford during the first Civil War, 'the distinction between civil and military guilt... presented problems that were to dog future debates over pardon, indemnity and oblivion' ${ }^{54}$ In 1663 these debates were in full swing, driven by Cavalier-Anglican reactionaries opposed to the toleration of former enemies. ${ }^{55}$ Given that some observers were already claiming that the Restoration government's neglect of ex-royalist officers was 'a Table-talk in most parts of Christendom', the furore which would have followed the execution of a muchwounded royalist veteran at the hands of ex-Cromwellians and Irish Catholics can readily be imagined.$^{56}$ It is therefore unsurprising that the death sentence from which the judges claimed they had 'noe Liberty to recede' was quietly forgotten: Apsley's report referred only to the defendant's 'misdemeanour' in slandering Major-General O'Brien, and claimed that the recommendation of the court had been that he should be disgracefully dismissed. ${ }^{57}$

The respective demeanours of the principal protagonists by mid-March show the extent to which the balance of power had shifted. Alarmed by rumours of large-scale defections to the Spanish, the Portuguese had now set up a commission of inquiry. Fanshawe began to exert more influence as soon as matters moved to Lisbon. He quickly obtained Molesworth's release, and a pass to return to England to 'make good his owne defence and to make good any Chardge hee hath against others' ${ }^{58}$ But Molesworth immediately began to cause more trouble. On 17 March, O'Brien burst into Fanshawe's residence, berated the ambassador for his meddling, and complained that Molesworth was at that moment

...inveighing in all companies heer against the authority and proceedings of the Councell of Warr, against his brother the Earl of Insiquin, and against himselfe the sayd Major Generall, particularly tht hee should have designes and debated upon the manner how to pass over with the English to the Spanyards. ${ }^{59}$

Fanshawe's subsequent letter to Molesworth indicates that even his patience was wearing thin. Relaying O'Brien's reluctant assent to the inquiry in Lisbon, the 
ambassador observed tartly that by this means 'whosever shall bee found faultie may be censured accordingly; and not in liberall discourses among private persons' ${ }^{60}$

O'Brien had also alleged that Molesworth had gone so far as to plot against his life. The ever-loyal Fanshawe had retorted that Molesworth 'and some others had mentioned to mee the like warning given to [him] and them from lay-hands, intimatinge moreover, tht the killing the other day of Captain Tresheyr was upon such an accompt by a contrary partie'. ${ }^{61}$ Tresheyr, or Tresaire, a junior officer in the Brigade, had died two weeks earlier at the hands of an English civilian named Stanley and rumours were circulating around Lisbon that this was no innocent quarrel. On 4 March, Captain John Belasyse had submitted a deposition claiming that Tresaire had been murdered and that just before his death the deceased had been attempting to convince fellow officers of O'Brien's intention to take the Brigade over to the Spanish. It was when Tresaire had threatened to take his suspicions to the authorities, Belasyse asserted, that he had been slain. ${ }^{62}$ Fanshawe could hardly bring himself to contemplate the possibility that officers within the Brigade might actually be murdering one another; nonetheless, he took the precaution of warning Molesworth: 'god forbid it should come to that, to the shame of Fellow-Subjects in the eyes of a forreigne nation, and certain chastizement to ensue (if not now here, yet from our Royall Master hereafter). ${ }^{63}$

The next day, 18 March, the Lisbon commissioners ordered the arrest of MajorGeneral O'Brien. ${ }^{64}$ Enraged, senior officers in the Brigade rode to Lisbon en masse to declare their support for their commander. Thomas Maynard, the English consul in Lisbon, wrote to Sir Henry Bennet, Secretary of State, on 31 March to report that 'there are now 10 or 12 of the Principal Commanders in Towne, whoe all proteste they believe that he is infinitely abused, and that this Charge is maliciously made by some of the officers under his Command'. ${ }^{65}$ Maynard assured Bennet that he could not believe either Molesworth or Belasyse guilty of baseless malice, but it should be noted that the consul was an ex-parliamentarian whose career had come to depend largely upon Fanshawe's favour. He had in addition publicly fraternised with Molesworth in Lisbon after the colonel's release. ${ }^{66}$

Several junior officers of the Brigade also wrote to declare their support for O'Brien; some specifically in order to challenge Belasyse's version of Tresaire's demise. By now, however, the Lisbon commission had become more interested in collecting testimony from Molesworth's allies such as Belasyse and Lieutenant Joseph White, in order to amass evidence that would retrospectively justify O'Brien's arrest. ${ }^{67}$

Fanshawe's letters during this period betray a growing sense of unease as the political cost of supporting Molesworth became increasingly apparent. Given that he had been largely responsible for O'Brien's downfall, the ambassador's letter to Sir Henry Bennet of 31 March is a masterpiece of back-pedalling. Despite admitting that he had endorsed Lisbon's decision to arrest O'Brien, Fanshawe indicated that he had had reservations; yet, he pleaded, in the interests of international relations it was 'very unfit for mee either openly to oppose, or so much as inwardly to censure the jealousies of a Crowne in such a case when it hath all at stake in the instantly approaching Campai[gn]'. ${ }^{68}$ It seems evident that Fanshawe hoped to obfuscate the fact that in his eagerness to protect Molesworth he had encouraged the Portuguese to interfere directly in the internal affairs of the Brigade. It was harder to gloss over the fact that MajorGeneral O'Brien was now in Portuguese custody, with even Fanshawe himself denied access. ${ }^{69}$ The ambassador's inference had had an even more significant consequence, in that Portuguese confidence had been so shaken by the allegations against O'Brien that 
Alfonso's ministers resolved thereafter to refuse the offer of any further troops from Ireland, on the grounds that these were likely to desert to the Spanish. ${ }^{70}$

If Molesworth's network in Portugal was now showing signs of strain his relatives in England were beginning to make headway. In mid-April, just as Fanshawe was completing arrangements for the return of Molesworth and O'Brien to London, Gervase Holles presented Charles II with a petition from Anne Molesworth on behalf of her husband. ${ }^{71}$ Inevitably, given the normal delays in receiving news from Portugal, the scenario she described was several weeks out of date. The wording of Holles' endorsement on the document, dated 15 April, similarly indicates that King Alfonso's letter advising of O'Brien's arrest, dated Lisbon 29 March (19 March in London), had not yet arrived in Whitehall. ${ }^{72}$ Nevertheless, the family network had achieved the important objective of bringing Molesworth's predicament to the personal attention of Charles II. Although all official correspondence relating to the affair had hitherto passed between Fanshawe, Maynard and Bennet, certain details in Anne Molesworth's petition indicate that the ambassador had also alerted Holles - who was ideally placed not only to promote his sister-in-law's petition, but also to apprise Inchiquin's enemies at Court. O'Brien's petition to the King soon after his arrival in England refers to just such a whispering campaign. The scandals and calumnies that had already been cast upon him, he complained, had been 'much augmented and agravated in England far beyond what is unjustly layd on him in Portugall.'73

Despite the gravity of the issues involved there was no public discussion of the unfolding drama in London. The news-books were largely dependent upon official sources for overseas news and Sir Henry Bennet controlled their editors to such a degree that he could ensure that nothing untoward found its way into print. In private discourse among the informed political elite, by contrast, the case appears to have excited considerable interest. Joseph Williamson apprised the Marquis of Ormond of developments on 16 May 1663, and at least one private newsletter had carried a report on the situation a week earlier. ${ }^{74}$ Thus, while the inquiry was followed keenly in some quarters, most around Whitehall remained blissfully unaware of events.

The inquiry commenced at the Cockpit - the octagonal theatre complex situated on the outskirts of Whitehall palace - on 5 May 1663. Unhappily for O'Brien, the two commissioners appointed were the Duke of Albemarle and Sir Henry Bennet. Apart from his long acquaintance with Molesworth, Albemarle had recently favoured the Holles family, issuing a commission for Holles' son from his private chambers in the Cockpit only four months earlier. These chambers now offered a suitably discrete venue to examine the dispute. ${ }^{75}$ Fanshawe had furnished Albemarle and Bennet with a dossier detailing the allegations made against O'Brien in Portugal and this now guided their line of questioning. ${ }^{76}$ One of the documents contained a detailed account of how Inchiquin and O'Brien had intended to 'debauch' the Brigade and how they were to be rewarded for their treachery. ${ }^{77}$ Such precise and fulsome intelligence was almost certainly too good to be true, but the commissioners could not afford to ignore it: Inchiquin had made many contacts during his military career, and he had been successful in enticing Irish troops to defect from Spanish service in Catalonia. Having by now returned to Ireland, the Earl provided the inquiry with written testimony.

If the respective networks of Guy Molesworth and Christopher O'Brien had been evenly matched in Portugal in terms of influence and numbers the contrast between the two parties in England was startling. Molesworth's friends and relatives had proved loyal and industrious, and had been effective in promoting the colonel's 
interests in both countries. O'Brien on leaving Portugal had been detached from his vociferous supporters in the Brigade and was now entirely reliant on the support of Inchiquin. But Inchiquin was himself isolated at Court and politically vulnerable, a situation which had perhaps arisen as much from his chequered personal reputation as it had from nationality or religion; after all, another Catholic Irishman, Colonel John Fitzgerald, for all that his recalcitrant subordinates in Tangier and detractors in Whitehall might disparage him as 'a man of no honour nor presence, nor little honesty, [who] endeavours to raise the Irish and supress the English interest there', could rest secure knowing that he was well protected by courtiers such as Viscount Hardinge and the Duke of York. ${ }^{78}$ Thus it was that far from giving his beleaguered brother an unequivocal endorsement Inchiquin's first priority was to protect his own skin. In an earlier confidential interview with Charles II, Inchiquin had made the proposal that the starving Brigade should be allowed to pass through the Spanish lines to find employment elsewhere. Belatedly acquainting Bennet with this information, the Earl stressed that he had 'never recommended any treachery; and no ill treatment could justify my brother in permitting it'. ${ }^{79}$ Worse still for O'Brien, in the course of his testimony Inchiquin had inadvertently substantiated Molesworth's accusation that the brothers had been approached by the Spanish but had not subsequently informed their superiors.

O'Brien, meanwhile, attempted to portray his detractors as a gang of malcontents. When asked about the circumstances surrounding Captain Tresaire's death, the major-general replied that Tresaire had been killed in a simple quarrel over a wager. He suggested that Belasyse had attempted to implicate him in the killing because the captain had been cashiered some time before by his brother Inchiquin. He observed that Lieutenant White had originally come to Portugal in Guy Molesworth's entourage. ${ }^{80}$ But despite the circumstantial nature of the evidence against him O'Brien was unable to convince Albemarle and Bennet of his innocence.

Four months after the Cockpit inquiry, Inchiquin petitioned Charles II to complain that his brother was still under close arrest. Having investigated Inchiquin's claim that this continued detention was at the insistence of the Portuguese authorities, the King pronounced O'Brien's detractors in Lisbon to be largely responsible. It is hard to believe that he meant anyone other than Fanshawe and his allies. Bennet had also shown himself disinclined to act in O'Brien's favour, having ignored a personal plea from the major-general soon after the inquiry that he be sentenced or released. ${ }^{81}$ It is noteworthy, therefore, that Charles now ordered Bennet to endorse Inchiquin's petition with the statement that the Portuguese had been unduly influenced by O'Brien's enemies. 'His Matie... hath commanded mee', Bennet further wrote, 'to declare that he finds no cause to lessen the good opinion he hath of the Earle of Inchiquin or his Brother', and intended to 'doe all things that shall offer themselves for their honr \& advantage. ${ }^{82}$ Such an emphatic intervention went beyond Charles's normal light touch, and Bennet's palpable discomfort illustrates how even powerful Restoration courtiers needed to take care how they involved themselves in the machinations of their inferiors. The activities of Molesworth's network had caused problems far beyond Whitehall, bringing royal displeasure on all concerned. However, despite this and the fact that Molesworth had been convicted of uttering reproachful words against him, Charles II granted the colonel a personal interview. The details of the interview have not survived, but Molesworth was later adamant that Charles had concluded by promising to 'take all occasions to do him good'. ${ }^{83}$ 
Molesworth's recurrent financial problems and incessant petitioning in the decades following the Portuguese affair appear to offer a stereotypical picture of a neglected Cavalier suffering at the hands of a perfidious and ungrateful state; certainly this was Molesworth's constant theme in his petitions after 1663, describing himself at one point as 'a monument of most unremarkable unprosperous Loyalty. ${ }^{84}$ His request on 30 May 1663 for a share of the profits arising from the sale of some impounded slaves, for example, met with a lukewarm response ${ }^{85}$ but then he had recently been at the epicentre of an affair that had caused huge disruption within the command structure of the AngloIrish forces in Portugal, undermined relations between Whitehall and Lisbon, and upset the delicate balance of factions at Charles' court. In addition, Inchiquin and O'Brien two servants considerably more useful to Charles II than Molesworth - had been sufficiently tainted by the colonel's allegations as to be rendered unemployable.

Fanshawe and Holles would also soon experience a downturn in their respective careers, although in neither case was this ostensibly connected with the Portuguese affair. Fanshawe was recalled to London in August 1663, and following a series of interviews with Charles was actually made a privy councillor. Nonetheless, in early 1664 he was removed from his post in Lisbon and replaced by Sir Robert Southwell an Irish-born Protestant with the ear of Inchiquin. ${ }^{86}$ Fanshawe was ordered to Madrid, where he died in May 1666 soon after he had again lost his position, having exceeded his authority by concluding a treaty with Spain. Holles, meanwhile, had suffered following a tussle with Bennet regarding their respective rights to present petitions to the King. ${ }^{87}$ Even Molesworth deserted him to solicit the patronage of Bennet (created Baron Arlington in 1665), for which the colonel was rewarded with an occasional portion of royal bounty and a share in a lottery scheme run in Ireland for the benefit of impoverished ex-royalist officers. ${ }^{88}$

Molesworth's petition of December 1666 was typical of those which he would submit to Charles II over the coming years, with details of his 'five and twenty wounds' incurred in the course of allegedly unblemished service to Charles I and a sanitised description of the internecine struggle on Barbados which had caused him to be 'banished \& totally ruined for his loyalty'. ${ }^{89}$ As regards his time in Portugal, Molesworth pleaded that he had served to 'the satisfaction of his Matie of Portugall', but made no mention of the court martial or the dispute with O'Brien. He reminded the King that,

... at the Pets returne from Portugall, your Matie was Gratiously pleased to promise the Petr that your Matie would take all occasions to do him good. But so it is may it please your Matie that the Petr wants nere after three yeares attendance \& his unprofitable voyage hath ingaged the Petr $\&$ his unhappy family in so great necessity as can be imagined. ${ }^{90}$

Interestingly, although he would remind the Crown of its moral obligations on several future occasions, Portugal was never mentioned in any subsequent petition.

Invariably Molesworth's constant request was for gainful employment. In late 1667 , with the state at war and desperate for experienced officers, he was given a commission in the foot regiment of William, Lord Alington. But the Second Dutch War 
was short-lived, and the regiment was soon disbanded under the terms of the Treaty of Breda. ${ }^{91}$ By November 1668 , Molesworth was at least partly restored to royal favour when the King responded favourably to a request for a life appointment as Keeper of the Customs House in London, 'much compassionating this Gentleman's Wants, and remembering how well he has on all occasions served his Maty \& his late Royall Father in the whole course of the late Rebellion'.$^{92}$ A permanent appointment remained elusive, however, and in September 1669 Molesworth made strenuous efforts to enlist support at Court. Given his impoverished state and his political insignificance his ability to network within the highest levels of government is remarkable. On 6 September he informed Arlington's associate Joseph Williamson,

Be pleased to continue your goodness to me in acquainting my Good Lord Arlington that I humbly moved His Grace the Duke of Albemarle with my Lords noble psuasione to joyne with the Duke [of York] in moving His Matie for favor and ease for me in my sad condition wch His Grace hath bin pleased to promise me. ${ }^{93}$

As a result of this impressive array of supporters, the King promised Molesworth the next company that fell vacant in the army, although whether he ever intended to honour this promise is debatable. A suitable post was eventually found when the colonel was appointed warehouse keeper in the Port of London in December 1671. ${ }^{94}$ Molesworth's financial problems were such, however, that within months he found himself in debtors' prison. His next petition, for all its deferential language, expressed frustration that no less than six foot companies had been allotted new commanders since he had been promised one in September 1669. As a result, Molesworth claimed, he was 'reduced to that misery that he must starve in Prison with his wife and three daughters who are growne women without yor Mats Mercy and Bounty'. ${ }^{95}$ Records show that Molesworth was able to resume his duties at the Port of London by December 1673. ${ }^{96}$ In October 1674 his powers of persuasion were still sufficiently potent to move the Earl of Danby to speak to the King on his behalf, resulting in a bounty of $£ 200 .{ }^{97}$ Guy Molesworth's last appearance in the archives is dated March 1676, when his warehouse keeper's salary was confirmed. ${ }^{98}$ The events of the Portuguese campaign and the exploits of the Anglo-Irish Brigade had long since faded from memory.

$$
* * *
$$

How could the intemperate behaviour of such a minor figure as Guy Molesworth have had such far-reaching consequences that it ultimately precipitated high-level commissions in Lisbon and Whitehall and the personal intervention of Charles II? The very composition of the forces deployed in Portugal and Tangier exemplify the problems facing the newly-restored British monarchy. It was imperative that the Crown dispose of Cromwell's old regiments and the predominantly Irish royalist units in Flanders as quickly as possible. There were obvious hazards in brigading them together in any theatre of operations, but the establishment of an exclusively ex-Cromwellian or Irish Catholic force in either Tangier or Portugal would have exposed Charles II to even worse criticism; as it was, there were many around Whitehall, like Pepys' friend $\mathrm{Mr}$ Cholmely, ready to believe that John Fitzgerald, the deputy governor of Tangier, was bent on turning that colony into a nest of papists. ${ }^{99}$ It was therefore politically expedient 
to ensure that the forces be mixed, and entirely predictable that the Crown should also seek to appoint a body of ex-royalist English officers sufficient to assure the political nation that matters in Portugal and Tangier would be largely in the hands of men of proven loyalty. There was an added bonus in that these appointments, together with the 1663 fund for indigent loyalist officers, went some way towards acknowledging Charles II's moral debt to those who had fought and suffered for the royalist cause during the Civil Wars and Interregnum. Molesworth, by virtue of his professional military background, undoubted fidelity and financial need, was in many ways an ideal candidate, although several of those who approved the appointments to the Anglo-Irish Brigade would have been well aware of his shortcomings. Albemarle, Rupert and Charles II all knew that in addition to his extensive military experience and devotion to the Crown the colonel was quarrelsome, meddlesome, impetuous and disdainful of authority. However, although his previous altercations had each caused a certain amount of fuss in their time, these had been essentially localised incidents which had only carried significant consequences for Molesworth and his immediate family. That the Portuguese affair proved far more serious was due to the conjunction of several factors. First and foremost the regimes in Lisbon and Whitehall were both extraordinarily fragile in 1663. Alfonso VI's government was threatened from within by the intrigues of courtiers and church leaders and from without by a Spain no longer distracted by war with France. In England, Charles II, with the monarchy still only recently restored and facing all manner of challenges, had an urgent need for income. This imperative lay at the core of negotiations to marry Charles to Catherine of Briganza. In 1663 much of the promised dowry had still not been paid; indeed, one of the main priorities of successive English ambassadors to Lisbon was to pursue the matter.

From Whitehall's perspective, then, the significance of the Anglo-Irish Brigade was twofold: firstly, it demonstrated England's commitment to the alliance (thereby reassuring Alfonso's ministers and encouraging settlement of the unpaid dowry); secondly, it was a receptacle into which the Restoration regime could deposit thousands of unwanted soldiers left over from the conflicts of the previous two decades. Molesworth was right to regard this volatile mixture of former Cromwellians, exroyalists and Irish Catholics 'as banished men' ${ }^{100}$ The men were not required to perform heroic deeds (although they did so on numerous occasions) nor make a particularly significant contribution to the Portuguese war effort. The officers were expected to maintain discipline and ensure that the Brigade did nothing to alarm their hosts. That the French also had a vested interest in the conduct of the Brigade is indicated by the critical comments offered by the commander of the French contingent in Portugal, Count Schomberg, during a visit to London in 1662. ${ }^{101}$ Any credible suggestion that the commanders of the Brigade were plotting to take their soldiers over to the Spanish was therefore bound to have immediate and serious repercussions.

Even within this sensitive environment Molesworth's activities might have caused relatively little disruption had he not been an intimate friend of Sir Richard Fanshawe and a relation of Gervase Holles. Major-General Christopher O'Brien did all he could to contain the problem, firstly by holding Molesworth and the other accused officers incommunicado and then by insisting that the court martial remain an internal matter. The death sentence handed down in Moura was always liable to be commuted, given Molesworth's contacts and his history of service to the Crown; but Fanshawe's meddling gave his friend licence to spread rumour and gossip in Lisbon and by his continued support gave credence to the allegations against O'Brien. Given the political 
and commercial stakes involved in the Portuguese alliance, anything which concerned the Lisbon authorities naturally concerned Whitehall. Even once the two antagonists had been safely extracted from Portugal, despite Charles II's efforts to redress the balance, the fact that O'Brien was isolated and Molesworth well supported influenced the chain of events during the Cockpit inquiry and its aftermath. John Miller has noted that although Charles II employed a number of Catholic officers in the early part of his reign, he became noticeably less eager to do so as feelings of anti-popery intensified. ${ }^{102}$ Although the affair was kept out of the public eye in England, and although Molesworth is not recorded as having cast any aspersions on O'Brien's religion, the tensions which had been revealed, and the speed with which the problem had escalated proved a clear concern for a monarch whose most earnest desire was always political equilibrium.

County lieutenancy papers and Quarter Sessions records show that the Restoration authorities took a close interest in the activities of even the humblest of the King's erstwhile enemies. ${ }^{103}$ In the 1660 s at least, they appear to have under-estimated the capacity of Charles I's old Cavaliers to cause comparable trouble. ${ }^{104}$ In fact, as the principal supporters of the restored Church and State, it could be argued that disgruntled Cavaliers possessed more potential to derail the Restoration than Fifth Monarchists, Quakers or any of the other radicals who featured in the reports regularly submitted to Sir Henry Bennet. As the Molesworth affair demonstrates, in contrast to the ineffectual republican coterie headed by Edmund Ludlow, Cavalier networks were genuinely able to operate in an international context, stretching all the way from a prison cell in Estremos to the corridors of Whitehall. Molesworth's history suggested that he was always likely to be a source of friction in Portugal, but it did not lead the authorities to suspect that he would prove to be the catalyst for a full-blown international incident; however, in considering whether he was a suitable person to hold a commission in the Anglo-Irish Brigade the authorities would have done well to have remembered that Guy Molesworth was not an individual but the centre of a network.

\footnotetext{
${ }^{1}$ I am grateful to Ann Hughes, Ian Atherton, Liudmyla Sharipova, and the anonymous reviewers of earlier drafts of this article for their suggestions and advice. All dates are taken from the point of origin of the original document.

2 The National Archives, Public Record Office, Kew, London (hereafter PRO) SP89/5, fo. 162.

${ }^{3}$ E.g., S. C. A. Pincus, Protestantism and Patriotism: Ideologies and the Making of English Foreign Policy, 1650-1668 (Cambridge, Cambridge University Press, 1996); D. Ormrod, The Rise of Commercial Empires: England and the Netherlands in the Age of Mercantilism, 1650-1770 (Cambridge, Cambridge University Press, 2003); G. Rommelse, The Second Anglo-Dutch War: International Raison D'Etat, Mercantilism and Maritime Strife (Hilversum, Uitgeverij Verloren, 2006).

${ }^{4}$ E.g., P. Seaward, The Cavalier Parliament and Reconstruction of the Old Regime 1661-1667 (Cambridge, Cambridge University Press, 1989); M. Goldie, T. Harris and P. Seaward (eds), The Politics of Religion in Restoration England (Oxford, Oxford University Press, 1990); J. Sawday, 'Re-writing a Revolution: History, Symbol and Text in the Restoration', The Seventeenth Century, 7:2 (1992), pp. 171199; J. Miller, After the Civil Wars: English Politics and Government in the Reign of Charles II (Harlow, Longman, 2000); T. Harris, Restoration: Charles II and His Kingdoms 1660-1685 (London, Allen Lane, 2005).

${ }^{5}$ R. Hutton, The Restoration: A Political and Religious History of England and Wales 1658-1667 (Oxford, Oxford University Press, 1985), p. 1.

${ }^{6}$ Pincus, Protestantism and Patriotism; C. G. Pestana, The English Atlantic in an Age of Revolution 16401661 (London, Harvard University Press, 2007).

${ }^{7}$ E.g., B. T. Duncan, T. Bentley, Uneasy Allies: Anglo-Portuguese Relations, 1642-1662 (New York, Vantage Press, 2001); L. M. E. Shaw, The Anglo-Portuguese Alliance and the English Merchants of Portugal 1654-1810 (Aldershot, Ashgate, 1998); L. M. E. Shaw, Trade, Inquisition, and the English Nation in Portugal 1650-1690 (Manchester, Carcanet Press, 1989); C. R. Boxer, 'Second Thoughts on the
} 
Anglo-Portuguese Alliance, 1661-1808', History Today, 36:6 (1986), pp. 22-26; G. L. Belcher, 'Spain and the Anglo-Portuguese Alliance of 1661: A Reassessment of Charles II's Foreign Policy at the Restoration', Journal of British Studies, 15:1 (Autumn, 1975), pp. 67-88; P. H. Hardacre, 'The English Contingent in Portugal, 1662-1668', Journal of the Society for Army Historical Research, 38 (1960), pp. 112-25; J. Childs, 'The English Brigade in Portugal 1662-1668', Journal of the Society for Army

Historical Research, 215 (Autumn 1975), pp. 135-47.

${ }^{8}$ Court of Chivalry, University of Birmingham [http://arts-

itsee.bham.ac.uk/AnaServer?chivalry+0+start.anv, accessed 13 July 2010].

${ }^{9}$ British Library [hereafter BL], Landsdowne MS 207c, fo. 410.

${ }^{10}$ BL Landsdowne MS 207c, fo. 192v; E. Peacock (ed.), The Army Lists of the Roundheads and Cavaliers (London, 1874), p. 74.

${ }^{11}$ Cheshire and Chester Archives DCC/14/50; DCC/14/51; A List of the Old and New Regiments of Horse and Foot under the Command of the Right Honourable Robert Sidney, Earle of Leicester (London, 1641), sig. [A2v].

${ }^{12}$ M. Ashley, General Monck (London, Jonathan Cape, 1977), pp. 43-4; BL Lansdowne MS 207c, fo. $409 \mathrm{v}$.

${ }^{13}$ Guy Molesworth to Prince Rupert, Bridgwater, 23 Jan 1645, BL Add. MS 18982, fo. 23.

${ }^{14}$ George Goring to Prince Rupert, Wells, 12 Apr 1645, BL Sloane MS 1519, fo. 54.

${ }^{15}$ E. Warburton (ed.), Memoirs of Prince Rupert (3 vols., London, Richard Bentley, 1849), iii, p. 51; F. Memegalos, George Goring (1608-1657): Caroline Courtier and Royalist General (Aldershot, Ashgate, 2007), pp. 229-30, 240; Original Letters of His Excellency Sir Richard Fanshawe, ed. A. Roper (London, 1701), p. 365.

${ }^{16}$ N. Dore (ed.), The Letter Books of Sir William Brereton (2 vols., Record Society of Lancashire and Cheshire, 123, 128, 1984, 1990), ii., p. 266 (no. 888) - a reference I owe to the kindness of Ian Atherton; P. Young, Naseby 1645 (London, Century, 1985), pp. 44-5, 262. See also Molesworth's 1667 petition to Charles II, PRO SP29/229, fo. 160.

${ }^{17}$ See Young, Naseby, p. 45, citing C. E. Long (ed.), Richard Symonds's Diary of the Marches of the Royal Army (Cambridge, Camden Society, 1997), p. 277. P. R. Newman (Royalist Officers of England and Wales (New York, Garland Press, 1981), p. 258) runs counter to BL Lansdowne MS 207c, fo. 409v (which confirms that Newman's reference is in fact Guy Molesworth's brother Edward). The officer stationed in Pendennis (Calendar of State Papers, Domestic [hereafter CSPD], 1645/7, p. 467) is most likely Guy Molesworth's cousin, John.

${ }^{18}$ N. Davis, The Cavaliers and Roundheads of Barbados (Georgetown, Argosy Press, 1887), p. 140; R. Dunn, Sugar and Slaves: The Rise of the Planter Class in the English West Indies 1624-1713 (2 ${ }^{\text {nd }} \mathrm{ed.}$, Kingston, Jamaica, Chapel Hill, University of North Carolina Press, 2000), p. 257.

${ }^{19}$ Lords Journals, xi, p. 2974; Royal Commission on Historical Manuscripts [hereafter HMC], Seventh Report of the Royal Commission on Historical Manuscripts (2 vols. in 1, 1879), I, i, p. 146.

${ }^{20}$ C. Campbell, Ancient Dominion of Virginia (Philadelphia, Lippincott \& Co, 1860), p. 251; A. L. Hatfield, Atlantic Virginia: Inter-colonial Relations in the Seventeenth Century (Philadelphia, University of Pennsylvannia Press, 2007), p. 284.

${ }^{21}$ HMC, Seventh Report, p. 146.

${ }^{22}$ M. A. LaCombe, 'Walrond, Humphrey (b. 1602, $d$. in or after 1668)', Oxford Dictionary of National Biography (Oxford, Oxford University Press, 2004) [http://www.oxforddnb.com/view/article/28605, accessed 19 July 2008].

${ }^{23}$ Lords Journal, xi, p. 2974.

${ }^{24}$ Gervase Holles' Register Book of Petitions, 1660-1670, BL Add. MS 5759, fos. 83v, 123v, 132;

Calendar of Treasury Books [Hereafter CTB], 1660-1667, p. 164.

${ }^{25}$ PRO SP89/6, fo. 23.

${ }^{26}$ Belcher, 'Spain and the Anglo-Portuguese Alliance', p. 72.

${ }^{27}$ Ibid., p. 74.

${ }^{28}$ Ibid., p. 72

${ }^{29}$ A List of Officers Claiming to the Sixty Thousand Pounds, etc., Granted by His Sacred Majesty for the Relief of the Truly-Loyal and Indigent Party (London, 1663), sig. A.

${ }^{30}$ Hardacre, 'English Contingent', pp. 114-15; Childs, 'English Brigade', p. 136.

${ }^{31}$ Calendar of State Papers, Venetian, 1661-4, p. 214. The murders and reprisals are mentioned in PRO SP89/6, fo. 221; and in Thomas Maynard to Edward, Earl of Clarendon, Lisbon, 7 Aug 1662, Bodleian 
MS Clarendon, II, fos. 90a-91, cited in Hardacre, 'English Contingent', p. 116, and Childs, 'English Brigade', pp. 138, 140.

${ }^{32}$ Sir Richard Fanshawe to Guy Molesworth, Lisbon, 10 Oct 1662, PRO SP89/5, fo. 123v.

${ }^{33}$ Sir Richard Fanshawe to Guy Molesworth, Lisbon, 17 Nov 1662, PRO SP89/5, fo. 146v.

${ }^{34}$ Petition of Guy Molesworth, Nicholas Pendennis and John Crossman to Sir Richard Fanshawe, Moura, 30 Jan 1663, PRO SP89/6, fo. 4.

${ }^{35}$ Sir Richard Fanshawe to Christopher O’Brien, Lisbon, 30 Jan 1663, PRO SP89/6, fo. 3.

${ }^{36}$ Petition of Anne Molesworth to Charles II, London, 15 Apr 1663, PRO SP89/6, fo. 93.

${ }^{37}$ Newman, Royalist Officers, p. 4.

${ }^{38}$ Certificate of James Apsley, Lisbon, 21 Mar 1663, PRO SP89/6, fo. 59.

${ }^{39}$ Articles of the court martial against Molesworth, Moura, 19 Feb 1663, PRO SP89/6, fo. 23.

${ }^{40}$ PRO SP89/6, fo. 23v.

${ }^{41}$ Poor conditions and desertion remained a problem for the Brigade throughout the campaign; Hardacre, 'English Contingent', pp. 116-17; Childs, 'English Brigade', pp. 136-8; Calendar of State Papers, Ireland, 1663-5 [hereafter CSPI], p. 78.

${ }^{42}$ PRO SP89/6, fo. $23 \mathrm{v}$.

43 Ibid.

${ }^{44}$ PRO SP89/6, fos. 23-23v.

${ }^{45}$ PRO SP89/6, fo. 23.

46 PRO SP89/6, fo. 24.

47 Ibid.

${ }^{48}$ PRO SP89/6, fo. 59.

49 PRO SP89/5, fo. 162.

${ }^{50}$ See J. Childs, The Army of Charles II (London, Routledge \& Kegan Paul, 1976), Appendix F; Ormond's order is in Bodleian MS Carte 163, fo. 43.

${ }^{51}$ E.g., Orders and Institutions of War, Made and Ordained by his Majesty, and by Him Delivered to his Generall, his Excellence the Earl of Newcastle (London, 1642), p. 5, articles 30 \& 31.

${ }^{52}$ See A. J. Smithers, The Tangier Campaign: The Birth of the British Army (Stroud, 2003), pp. 94-5, 121.

${ }^{53}$ Smithers, Tangier Campaign, p. 55; S. Pepys, The Diary of Samuel Pepys, ed. R. Latham and W.

Matthews (11 vols., London, Harper Collins, 1970), V, pp. 344-5 (diary entry for 15 December 1664).

${ }^{54}$ B. Donagan, 'Atrocity, War Crime, and Treason in the English Civil War', American Historical Review, 99: 4 (Oct 1994), p. 1141.

${ }^{55}$ E.g., The Intelligencer, No. 3 (14 Sept 1663), p. 23; Roger L'Estrange, Toleration Discuss'd (London, 1663), pp. 56-7, 59, and Molesworth's own opinions in PRO SP89/6, fo. 23v.

${ }^{56}$ C. Hammond, Truth's Discovery; or the Cavalier's Case Clearly Stated (London, 1664), p. 5

${ }^{57}$ PRO SP89/6, fo. 59.

${ }^{58}$ Sir Richard Fanshawe to Guy Molesworth, Lisbon, 17 Mar 1663, PRO SP89/6, fo. 35.

59 Ibid.

${ }^{60}$ Ibid.

${ }^{61}$ PRO SP89/6, fo. 35v.

${ }^{62}$ Certificate of John Belasyse, Lisbon, 4 Mar 1663, PRO SP89/5, fo. 87; see also the examination of

Christopher O'Brien at the Cockpit, London, 7 May 1663, PRO SP89/6, fos. 123v, $125 \mathrm{v}$.

${ }^{63}$ PRO SP89/6, fo. 35v.

${ }^{64}$ Summary of papers transmitted to London by Fanshawe, 5 May 1663, PRO SP89/6, fo. 117.

${ }^{65}$ Thomas Maynard to Sir Henry Bennet, Lisbon, 31 Mar 1663, PRO SP89/6, fo. 80v.

66 Thomas Maynard to Sir Richard Fanshawe, Lisbon, 14 Mar 1663, PRO SP89/6, fo. 31.

${ }^{67}$ Certificate of Lawrence Dempsey, Charles Croke and William Moore, Lisbon, 29 Mar 1663, PRO SP89/6, fo. 73; evidence of Joseph White, Lisbon, n.d., PRO SP89/5, fo. 160; PRO SP89/6, fo. 123.

${ }^{68}$ Sir Richard Fanshawe to Sir Henry Bennet, Lisbon, 31 Mar 1663, PRO SP89/6, fo. 77.

${ }^{69}$ Sir Richard Fanshawe to Antonio de Sousa de Macedo, Lisbon, 31 Mar 1663, PRO SP89/6, fo. 83.

${ }^{70}$ Hardacre, 'English Contingent', p. 120, citing Thomas Brown (ed.), Miscellanea Aulica (London, 1702), pp. 339-40; CSPI 1663-5, pp. 362-3, 366-8, 382.

${ }^{71}$ Passport signed by Sir Richard Fanshawe for Christopher O’Brien, Lisbon, 8 Apr 1663, PRO SP89/6, fo. 86; Petition of Anne Molesworth to Charles II, London, 15 Apr 1663, PRO SP89/6, fo. 93.

${ }^{72}$ Alfonso VI to Charles II, Lisbon, 29 Mar 1663, PRO SP89/6, fo. 74.

${ }^{73}$ Petition of Christopher O’Brien to Charles II [London?], n.d., PRO SP89/5, fo. 159. 
${ }^{74}$ Joseph Williamson to James, Marquis of Ormond, Whitehall, 16 May 1663, Bodleian MS Carte 222, fo. 13; news letter, 8 May 1663, CSPD 1663-4, p. 132.

${ }^{75}$ HMC, Report on the Manuscripts of the Duke of Buccleuch and Queensbury (4 vols. in 3, 1899-1926), I, p. 540.

${ }^{76}$ PRO SP89/6, fos. 116, 119, 123, 204.

${ }^{77}$ PRO SP89/6, fo. 116.

${ }^{78}$ Pepys, Diary, V, p. 302 (20 October 1664); III, p. 204 (24 September 1662); IV, p. 116 (29 April 1663); V, p. 345 (15 December 1664).

${ }^{79}$ Murrough, Earl of Inchiquin to Sir Henry Bennet, Limerick, 15 May 1663, CSPI, 1663-65, p. 78.

${ }^{80}$ PRO SP89/6, fos. 123-123v.

${ }^{81}$ PRO SP29/73, fo. 63; Christopher O'Brien to Sir Henry Bennet, London, 15 May 1663, CSPD, 1663-4, p. 139.

${ }^{82}$ Petition of Murrough, Earl of Inchiquin to Charles II, London, 17 Aug 1663, PRO SP44/13, fo. 346; see also Marquis de Sande to Sir Henry Bennet, London, 7 July 1663, PRO SP89/6, fo. 155.

${ }^{83}$ Petition of Guy Molesworth to Charles II, Dec 1666, PRO SP29/186, fo. 78.

${ }^{84}$ Petition of Guy Molesworth to Charles II, [1667], PRO SP29/229, fo. 160.

${ }^{85}$ BL Add. MS 5759, fo. 132; Calendar of State Papers, Colonial, America and West Indies, 1661-1668, p. 134.

${ }^{86}$ BL Add. MS 34336, fos. 1-2; BL Add. MS 46947B, fos. 88, 102.

${ }^{87}$ B. D. Henning, The House of Commons 1660-1690, II (London, Secker \& Warburg, 1983), p. 566; B. Weiser, 'Access and Petitioning during the Reign of Charles II', in ed. E. Cruickshanks, The Stuart Courts (Stroud, Sutton, 2000), p. 206.

${ }^{88}$ CTB, 1660-1667, p. 596; CTB, 1667-1668, p. 604; CSPD, 1668-9, p. 222; CSPI, 1666-9, pp. 687, 772; CSPD, 1668-9, pp. 137, 300, 330, 429, 467; CSPD, 1675-7, p. 320; E. C. L'Estrange, Lotteries and Sweepstakes (London, Heath Cranton Ltd., 1932), pp. 328-9. See also the letter of Sir William Neale to Joseph Williamson, Wrexham, 13 Feb 1669, PRO SP29/255, fo. 149.

${ }^{89}$ PRO SP29/186, fo. 78. See also later petitions in PRO SP29/229, fos. 159, 160; PRO SP29/270, fo. 65; PRO SP29/319, fo. 344 .

${ }^{90}$ PRO SP29/186, fo. 78.

${ }^{91}$ C. Dalton (ed.) English Army Lists and Commission Registers, 1661-1714 (6 vols., London, Eyre \& Spottiswoode, 1892), i, p. 80.

${ }^{92}$ PRO SP44/18, fo. 341.

${ }^{93}$ Guy Molesworth to Joseph Williamson, 6 Sept 1669, PRO SP29/265, fo. 18; petition of Guy Molesworth to Charles II, Sept 1669, PRO SP29/270, fo. 65.

${ }^{94}$ CTB, 1669-72, p. 1164.

${ }^{95}$ Petition of Guy Molesworth to Charles II, 1672, PRO SP29/319, fo. 193. For Molesworth's earlier spell in debtors' prison see his petitions to Charles II in 1667: PRO SP29/229, fos. 159, 160.

${ }^{96}$ CTB, 1669-72, pp. 819, 990, 1000, 1152, 1164; CTB, 1672-1675, p. 451.

${ }^{97}$ CTB, 1672-1675, pp. 258, 260, 604.

${ }^{98}$ CTB, 1676-1679, pp. $115,171$.

${ }^{99}$ Pepys, Diary, V, p. 302 (20 October 1664).

${ }^{100}$ At the cessation of hostilities in 1668 only 800 soldiers of the Brigade survived out of some 4,500 deployed. 400 of these survivors were promptly shipped to Tangier.

${ }^{101}$ Gilbert Burnet, History of His Own Time (Oxford, Clarendon Press, 1823), vol. 1, pp. 294-5, quoted in Childs, 'English Brigade', p. 136. Schomberg was eventually given command of the Anglo-Irish Brigade. 102 J. Miller, 'Catholic Officers in the Later Stuart Army', English Historical Review, 88:346 (January, 1973), p. 38.

${ }^{103}$ E.g. Deputy lieutenants' reports and examinations of former parliamentarian soldiers in Braintree, January 1660, Essex Record Office, D/Deb/95, fos. 115-119; information of Henry Cliff before Sir Henry Wright JP, November 1663, ERO Q/SR 399/12.

${ }^{104}$ The crown had become noticeably more sensitive to expressions of Cavalier-Anglican discontent by 1671, when Charles II ordered Lord John Lucas's critical speech in the House of Lords to be burnt by the common hangman; D. J. Appleby, Our Fall Our Fame: The Life and Times of Sir Charles Lucas (Newtown, Jacobus Press, 1996), p. 162.

\section{Dr David J. Appleby}


School of History, University of Nottingham

david.appleby@nottingham.ac.uk

\section{**LAST PAGE**}

